\title{
The Analysis of Students' Attitudes Construction Based on Pancasila Profile to be Integrated with Teacher's Lesson Plan in Junior High School in Pandemic Era
}

\author{
Diah Puji Nali Brata ${ }^{1 *}$,Edy Setiyo Utomo ${ }^{2}$, Sukardi Sukardi ${ }^{3}$ \\ ${ }^{1,2}$ STKIP PGRI Jombang \\ ${ }^{3}$ Universitas Palangka Raya \\ "Corresponding author. Email: pujidiah37@yahoo.com
}

\begin{abstract}
This study aimed to investigate the construction of Pancasila-profile-based attitude reinforcement integrated into lesson plan by teachers for junior high school students during online teaching. It used descriptive-quantitative approach. The sample of this study consisted of 278 junior high school. The instrument of this study consisted of questionnaire and lesson plan. The collected data was analyzed using SPSS 24.0. As the result, the output of SPSS 24.0 showed that the Sig. (2 tailed) score of being faithful, pious to The One Almighty God, noble, globally harmonious in diversity, mutually cooperative, autonomous, critical thinking, and creative was $0.000<0.005$. It indicated a significant correlation among them. The construction of lesson plan by teachers should have either modification or addition on their indicators, objectives, and basic competence that students expected. Furthermore, teachers were expected to be able to do self-internalization in order to support their students' development integrated to lesson plan.
\end{abstract}

Keywords: Attitude, Pancasila Profile, Lesson Plan

\section{INTRODUCTION}

Lesson plan is definitely inseparable with the process of learning in class. It is useful as reference for teachers to manage their class, students, and the process of teaching and learning itself thoroughly. During pandemic Covid-19, the process of teaching and learning has changed from having face-to-face (offline) meeting to online one. Therefore, teachers are required to do some changes as well, including their lesson plan. [1] suggested that lesson plan played an important role in exploring class activities, experiences of learning, and technique of assessment. Hence, it could improve the quality of teaching and students' active involvement. Furthermore, lesson plan was an important process for teachers in reflecting what they would teach, how to teach, and how to evaluate them all [2][3]. Thus, the process of constructing lesson plan was a big challenge for teachers.
One aspect of teachers' lesson plan is assessment of students' attitudes or affective. This assessment should be well designed in order to have a comprehensive illustration about the development of students' attitudes. Currently, developing students' attitudes is considered urgent, useful, yet challenging for every community of school. They may encourage students and their other community to develop personal relationship, intrapersonal in order to understand their characters. In addition, they may build a community which has care to one another [4]. However, teachers sometimes cannot implement their lesson plan optimally, especially in assessment. Lesson plan was fundamental for improving the quality of teaching, and the capacity of learning [1]. In its implementation, however, it was seldom applied in class. Whereas, the aspect of assessment, in particular to students' attitude, was the benchmark for teachers' performance in constructing their students' characters. What was in line with character building was national movement as an attempt to create and raise young 
generations with good characters through role models, teaching. It needs pro-active participation from schools, society, and government to embed the values of good characters about caring, honesty, fairness, responsibility, and esteem to self and others[5][6].

The Ministry of Education and Culture [7], under their authority, committed to create Pancasilais Students as Indonesia long life learners with global competences and Pancasila-based attitudes. The profile of Pancasilais Student as the reinforcement of character building that consisted of some values including: (1) be faithful, pious to The One Almighty God, and noble, (2) globally harmonious in diversity, (3) mutually cooperative, (4) autonomous, (5) critical in thinking, and (6) creative. Some indicators embedded in the values of Pancasila profile are: (1) be faithful, pious to The One Almighty God, and noble emphasizes on understanding morality, spirituality, and good ethics, and those all are the result of character building; (2) globally harmonious in diversity emphasizes on loving the variety of cultures, religions, and races inside or outside their country, and also defines them as global citizen; (3) mutually cooperative emphasizes on having competence of collaboration for teamwork; (4) autonomous emphasizes on being independently motivated to improve their competences; (5) critical in thinking emphasizes on having competence for problem solving; and (6) creative emphasizes on creating new things, innovating autonomously, and loving arts and cultures. To optimally embedding those values, it needs habituation, students' coaching, school management, and teaching. Therefore, every unit of education does planning, implementation, and assessment appropriately in order to reach the profile of Pancasilais students.

Since pandemic Covid-19 came, it requires every unit of education, from elementary to advanced level, to do online teaching and learning. The Ministry of Education and Culture [7] stated that learning had several characteristics including (1) learners should be able to construct and build autonomously (constructivism); (2) collaboration between learners should happen to develop their insights and collectively solve problems (social constructivism); (3) an inclusive community of learners should be made; (4) implementing and utilizing websites through internet access, virtual and/or digital class; and (5) interactivities, autonomy, accessibility, and enrichment.

Hence, this study aimed to analyse the assessment of attitudes by students during online learning that teachers had constructed. Besides, it also analyzed the junior high school teachers' lesson plan related to the aspect of attitude assessment integrated with Pancasila profile. It could be useful as reference for teachers to develop such a reliable and proper lesson plan which made them able to do appropriate and measured assessment on their students' attitudes.

\section{RESEARCH METHOD}

\subsection{Research Design}

The research design of this study was descriptivequantitative, which data was collected from questionnaires distributed to the sample of this study. In addition, we analysed teachers' lesson plan as well. [8] suggested that quantitative research referred to a study which data was in the form of scores, and it was analyzed statistically. Descriptive statistic was applied to explain the research object.

\subsection{Participants}

The respondent of this study consisted of 278 junior high school students in East Java. More specifically, they were from SMP Negeri 1 Gresik, SMP Islam Roushon Fikr dan SMP Negeri 2 Mojokerto. 172 students $(61.9 \%)$ were in $7^{\text {th }}$ grade and 106 students $(38.1 \%)$ were in $8^{\text {th }}$ grade. In terms of gender, 137 students $(49.3 \%)$ were males and 141 students $(50.7 \%)$ were females. They filled in the questionnaires of attitude assessment they got online through Google Form.

\subsection{Questionnaire and Coefficient of Reliability}

The instrument of this study was questionnaire that consisted of 20 items of questions that aimed to identify the attitude assessment by teachers. It referred to six values of attitudes including (1) be faithful, pious to The One Almighty God, and noble; (2) globally harmonious in diversity; (3) mutually cooperative; (4) autonomous; (5) critical in thinking; and (6) creative. Every statement in the questionnaire consisted of three options: never, sometimes, and always. The conversion of each of those options was: 1 for never, 2 for sometimes, and 3 for always.

Dimension of being faithful, pious to The One Almighty God, and noble had 5 indicators in Table 1.

Table 1. Dimension and Indicator

\begin{tabular}{|c|c|c|}
\hline \begin{tabular}{|l|} 
Dimension of \\
Pancasila Profile
\end{tabular} & Indicator & Code \\
\hline \multirow{5}{*}{$\begin{array}{l}\text { Being faithful, } \\
\text { pious to The One } \\
\text { Almighty God, and } \\
\text { noble }\end{array}$} & Attitudes in religion & $1 \mathrm{~A}$ \\
\hline & Personal attitude & $1 \mathrm{~B}$ \\
\hline & Attitudes to human & $1 \mathrm{C}$ \\
\hline & Attitude to the nature & $1 \mathrm{D}$ \\
\hline & Attitude to the nation & $1 \mathrm{E}$ \\
\hline \multirow{3}{*}{$\begin{array}{l}\text { Being globally } \\
\text { harmonious in } \\
\text { diversity }\end{array}$} & $\begin{array}{l}\text { Recognizing and } \\
\text { appreciating cultures }\end{array}$ & $2 \mathrm{~F}$ \\
\hline & $\begin{array}{l}\text { Intercultural } \\
\text { communication } \\
\text { skills in interaction } \\
\text { with others }\end{array}$ & $2 \mathrm{G}$ \\
\hline & Reflection and & $2 \mathrm{H}$ \\
\hline
\end{tabular}




\begin{tabular}{|c|c|c|}
\hline \begin{tabular}{|l|} 
Dimension of \\
Pancasila Prile
\end{tabular} & Indicator & Code \\
\hline & $\begin{array}{l}\text { responsibility to the } \\
\text { experience of being } \\
\text { harmonious in } \\
\text { diversity }\end{array}$ & \\
\hline \multirow{3}{*}{$\begin{array}{l}\text { Being mutually } \\
\text { cooperative }\end{array}$} & Collaboratuon & $3 \mathrm{I}$ \\
\hline & Caring & $3 \mathrm{~J}$ \\
\hline & Sharing & $3 \mathrm{~K}$ \\
\hline \multirow[t]{2}{*}{ Being autonomous } & Self-awareness & $4 \mathrm{~L}$ \\
\hline & $\begin{array}{l}\text { Encountered } \\
\text { situation as well as } \\
\text { self-regulation }\end{array}$ & $4 \mathrm{M}$ \\
\hline \multirow[t]{4}{*}{$\begin{array}{l}\text { Being critical in } \\
\text { thinking }\end{array}$} & $\begin{array}{l}\text { Collecting and } \\
\text { processing } \\
\text { information and } \\
\text { ideas }\end{array}$ & $5 \mathrm{~N}$ \\
\hline & $\begin{array}{l}\text { Analyzing and } \\
\text { evaluating any } \\
\text { logical reasoning }\end{array}$ & $5 \mathrm{O}$ \\
\hline & $\begin{array}{l}\text { Reflecting the } \\
\text { thoughts and the } \\
\text { process of thinking }\end{array}$ & $5 \mathrm{P}$ \\
\hline & Making conclusion & $5 Q$ \\
\hline \multirow[t]{3}{*}{ Being creative } & $\begin{array}{l}\text { Generating genuine } \\
\text { ideas }\end{array}$ & $6 \mathrm{R}$ \\
\hline & Creating works & $6 \mathrm{~S}$ \\
\hline & $\begin{array}{l}\text { Taking } \\
\text { actions }\end{array}$ & $6 \mathrm{~T}$ \\
\hline
\end{tabular}

\subsection{Technique of Data Analysis}

The result of questionnaires previously filled in by 278 respondents was then processed using SPSS 24.0. Meanwhile, descriptive-statistic was for analysing the lesson plan that teachers had designed during their online teaching. It aimed to identify how the integration of each attitude that teachers had designed corresponded to the indicators of Pancasila profile. For data analysis, we used r-test in accordance to the dimension and indicators of each attitude through SPSS 24.0.

\section{RESULT}

A survey had been distributed to 278 students of junior high school. It related to students' attitude reinforcement that teachers had constructed during online teaching. The attitudes involved being faithful and noble, globally harmonious in diversity, mutually cooperative, autonomous, critical in thinking, and creative. Figure 1 presented the mean score of each of those attitudes according to the result of the questionnaires that respondents had filled in, as follow. According to Figure 1, the mean score of being faithful, pious to The One Almighty God, and noble attitude was 2.65. Next, the mean score of being globally harmonious in diversity was 2.64. The mean score of being mutually cooperative attitude was 2.40 . The mean score of being autonomous attitude was 2.85. The mean score of being critical in thinking attitude was 2.70, while the mean score of being creative was 2.87 . Overall, the mean score of the entire attitudes was 2.69.

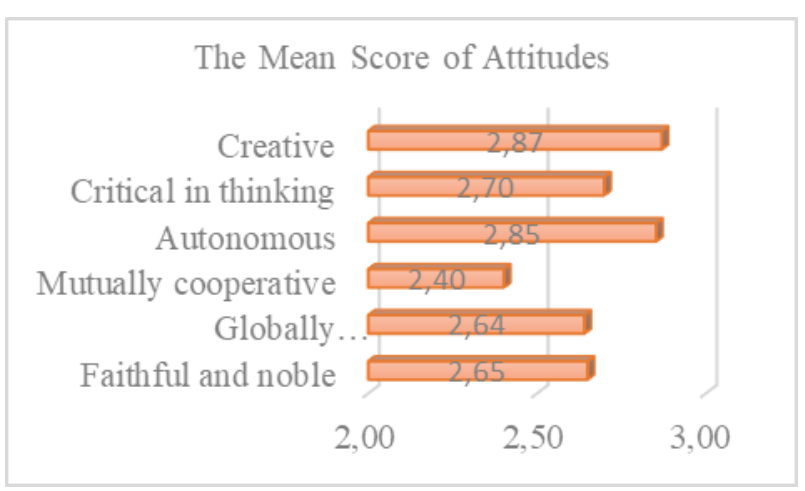

Figure 1. The mean score of attitudes

The attitudes with higher mean score were being autonomous and creative, while the attitude with lower mean score was being mutually cooperative. It indicated that teachers had reinforced the students' attitudes of being autonomous and creative well during online teaching. The assessment of those two attitudes referred to the information that students collected to support their learning. However, the assessment of being mutually cooperative attitude could not be optimally reinforced due to the restriction during pandemic period.

Next, Figure 2 presented the result of the students' responses on each statement in the questionnaires, as follow.

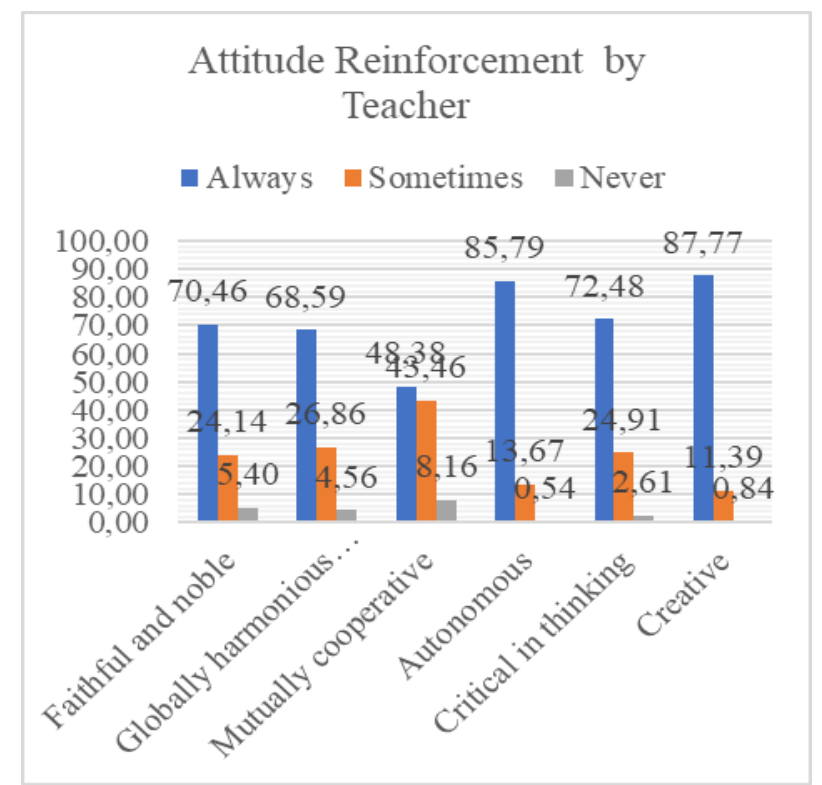

Figure 2. Attitude Reinforcement by Teacher 
According to Figure 2, the assessment percentage of being faithful, pious to The One Almighty God and noble attitude was $70.46 \%$ for always, $24.14 \%$ for sometimes, and $5.40 \%$ for never. Towards being globally harmonious in diversity, it was $68.59 \%$ for always, $26.86 \%$ for sometimes, and $4.56 \%$ for never. Towards being mutually cooperative attitude, it was $48.38 \%$ for always, $43.46 \%$ for sometimes, and $8.16 \%$ for never. Towards being autonomous attitude, it was percentage while being creative had the lowest one. In never option, being mutually cooperative was the highest, while being autonomous was the lowest.

Next, Table 2 presented each aspect of attitude integrated with Pancasila profile. The table showed that being creative attitude, in particular to taking original actions, reached the highest score with 252 students. On the other hand, being mutually cooperative attitude, in particular to collaboration, reached the lowest approval

Table 2. Mean Score of Each Dimension and Indicator

\begin{tabular}{|c|c|c|c|c|c|c|}
\hline \begin{tabular}{|l|}
$\begin{array}{l}\text { Dimension of Pancasila } \\
\text { Profile }\end{array}$ \\
\end{tabular} & Indicator & Code & Always & Sometimes & Never & Mean \\
\hline \multirow{5}{*}{$\begin{array}{l}\text { Being faithful, pious to } \\
\text { The One Almighty } \\
\text { God, and noble }\end{array}$} & Attitudes in religion & $1 \mathrm{~A}$ & 220 & 50 & 8 & 2,76 \\
\hline & Personal attitude & $1 \mathrm{~B}$ & 168 & 93 & 17 & 2,54 \\
\hline & Attitudes to human & $1 \mathrm{C}$ & 219 & 55 & 3 & 2,77 \\
\hline & Attitude to the nature & $1 \mathrm{D}$ & 141 & 93 & 43 & 2,35 \\
\hline & Attitude to the nation & $1 \mathrm{E}$ & 230 & 44 & 4 & 2,81 \\
\hline \multirow[t]{3}{*}{$\begin{array}{l}\text { Being globally } \\
\text { harmonious in diversity }\end{array}$} & $\begin{array}{l}\text { Recognizing and } \\
\text { appreciating cultures }\end{array}$ & $2 \mathrm{~F}$ & 195 & 71 & 12 & 2,66 \\
\hline & $\begin{array}{l}\text { Intercultural } \\
\text { communication skills in } \\
\text { interaction with others }\end{array}$ & $2 \mathrm{G}$ & 242 & 36 & 0 & 2,87 \\
\hline & $\begin{array}{l}\text { Reflection and } \\
\text { responsibility to the } \\
\text { experience of being } \\
\text { harmonious in diversity }\end{array}$ & $2 \mathrm{H}$ & 135 & 117 & 26 & 2,39 \\
\hline \multirow{3}{*}{$\begin{array}{l}\text { Being mutually } \\
\text { cooperative }\end{array}$} & Collaboratuon & $3 \mathrm{I}$ & 108 & 142 & 27 & 2,29 \\
\hline & Caring & $3 \mathrm{~J}$ & 138 & 122 & 18 & 2,43 \\
\hline & Sharing & $3 \mathrm{~K}$ & 157 & 98 & 23 & 2,48 \\
\hline \multirow[t]{2}{*}{ Being autonomous } & Self-awareness & $4 \mathrm{~L}$ & 246 & 31 & 1 & 2,88 \\
\hline & $\begin{array}{l}\text { Encountered situation as } \\
\text { well as self-regulation }\end{array}$ & $4 \mathrm{M}$ & 231 & 45 & 2 & 2,82 \\
\hline \multirow[t]{4}{*}{ Being critical in thinking } & $\begin{array}{l}\text { Collecting and } \\
\text { processing information } \\
\text { and ideas }\end{array}$ & $5 \mathrm{~N}$ & 223 & 55 & 0 & 2,80 \\
\hline & $\begin{array}{l}\text { Analyzing and } \\
\text { evaluating any logical } \\
\text { reasoning }\end{array}$ & 50 & 200 & 69 & 9 & 2,69 \\
\hline & $\begin{array}{l}\text { Reflecting the thoughts } \\
\text { and the process of } \\
\text { thinking }\end{array}$ & $5 \mathrm{P}$ & 150 & 109 & 19 & 2,47 \\
\hline & Making conclusion & $5 Q$ & 233 & 44 & 1 & 2,83 \\
\hline \multirow[t]{3}{*}{ Being creative } & Generating genuine ideas & $6 \mathrm{R}$ & 250 & 26 & 2 & 2,89 \\
\hline & Creating works & $6 \mathrm{~S}$ & 230 & 45 & 3 & 2,82 \\
\hline & Taking original actions & $6 \mathrm{~T}$ & 252 & 24 & 2 & 2,9 \\
\hline
\end{tabular}

$85.79 \%$ for always, $13.67 \%$ for sometimes, and $0.54 \%$ for never. Towards being critical in thinking, it was $72.48 \%$ for always, $24.91 \%$ for sometimes, and $2.61 \%$ for never. Last, towards being creative attitude, it was $87.77 \%$ for always, $11.39 \%$ for sometimes, and $0.84 \%$ for never. Looking into these results, it found that students mostly took always option for each of the attitude assessment their teacher showed during online teaching, and thus, it had the highest percentage for each assessment. More specifically, being creative had the highest score in always option, while being mutually cooperative was the lowest. Otherwise, in sometimes option, being mutually cooperative had the highest with 108 students. For sometimes category, the highest score with 142 students went to being mutually cooperative, in particular to collaboration, while the lowest score with 24 students went to being creative attitude, in particular to taking original action. For never category, the highest score with 43 students went to being faithful, pious to The One Almighty God, and noble attitude, in particular to attitudes to the nature, while the lowest one went to being globally harmonious in diversity attitude, in particular to intercultural communication skill in interaction with others. Next, the mean score of each indicator was 2.67. However, the lowest mean score which was 2.29 went to 
collaboration, while the highest one went to taking original action. According to the result of assessment above, some attitudes that teachers should improve more were attitudes to the nature, reflection and responsibility to the experience of being harmonious in diversity, collaboration, caring and sharing, reflecting the thought and the process of thinking.

According to the result of the questionnaire, it found correlations between dimensions of attitude assessment integrated with Pancasilais student profile. The correlations aimed to identify the significance and effect of each dimension. Table 3 presented these correlations. indicated a positive correlation in which the higher the faithful and noble attitude, the higher the attitude of being globally harmonious in diversity would be. The correlation between being faithful and noble and mutually cooperative attitudes was $0.000<0.05$. It indicated a positive correlation as well. Next, the correlation between being faithful and noble and being autonomous was $0.000<0.05$. It indicated a positive correlation. The correlation between being faithful and noble and critical thinking was $0.000<0.05$, indicating a positive correlation. The correlation between being faithful and noble and being creative was $0.001<0.05$, indicating a positive correlation. The output of SPSS

Table 3. Correlation between dimension of attitude

\begin{tabular}{|c|c|c|c|c|c|c|c|c|}
\hline & & Faithful & $\begin{array}{l}\text { Globally } \\
\text { harmonio } \\
\text { us in } \\
\text { diversity }\end{array}$ & $\begin{array}{c}\text { Mutually } \\
\text { cooperative }\end{array}$ & $\begin{array}{l}\text { Autonomo } \\
\text { us }\end{array}$ & $\begin{array}{l}\text { Critical in } \\
\text { thinking }\end{array}$ & Creative & Mean \\
\hline \multirow[t]{3}{*}{ Faithful } & \begin{tabular}{|l|} 
Pearson \\
Correlation
\end{tabular} & 1 & $.463 * *$ & $.427 * *$ & $.408 * *$ & $.457 * *$ & $.193 * *$ & $.771 * *$ \\
\hline & Sig (2-tailed) & & .000 & .000 & .000 & .000 & .001 & .000 \\
\hline & $\mathrm{N}$ & 278 & 278 & 278 & 278 & 278 & 278 & 278 \\
\hline \multirow{3}{*}{$\begin{array}{l}\text { Globally } \\
\text { harmonious in } \\
\text { diversity }\end{array}$} & $\begin{array}{l}\text { Pearson } \\
\text { Correlation }\end{array}$ & $.463 * *$ & 1 & $.422 * *$ & $.359 * *$ & $.435 * *$ & $.210 * *$ & $.693 * *$ \\
\hline & Sig (2-tailed) & .000 & & .000 & .000 & .000 & .000 & .000 \\
\hline & $\mathrm{N}$ & 278 & 278 & 278 & 278 & 278 & 278 & 278 \\
\hline \multirow[t]{3}{*}{$\begin{array}{l}\text { Mutually } \\
\text { cooperative }\end{array}$} & \begin{tabular}{|l|} 
Pearson \\
Correlation \\
\end{tabular} & $.427 * *$ & $.422 * *$ & 1 & $.330 * *$ & $.507 * *$ & $.188 * *$ & $.727 * *$ \\
\hline & Sig (2-tailed) & .000 & .000 & & .000 & .000 & .002 & .000 \\
\hline & $\mathrm{N}$ & 278 & 278 & 278 & 278 & 278 & 278 & 278 \\
\hline \multirow[t]{3}{*}{ Autonomous } & \begin{tabular}{|l|} 
Pearson \\
Correlation
\end{tabular} & $.408 * *$ & $.359 * *$ & $.330 * *$ & 1 & $.433 * *$ & $.404 * *$ & $.624 * *$ \\
\hline & Sig (2-tailed) & .000 & .000 & .000 & & .000 & .000 & .000 \\
\hline & $\mathrm{N}$ & 278 & 278 & 278 & 278 & 278 & 278 & 278 \\
\hline \multirow[t]{3}{*}{$\begin{array}{l}\text { Critical in } \\
\text { thinking }\end{array}$} & \begin{tabular}{|l|} 
Pearson \\
Correlation
\end{tabular} & $.457 * *$ & $.435 * *$ & $.507 * *$ & $.433 * *$ & 1 & $.428 * *$ & $.794 * *$ \\
\hline & Sig (2-tailed) & .000 & .000 & .000 & .000 & & .000 & .000 \\
\hline & $\mathrm{N}$ & 278 & 278 & 278 & 278 & 278 & 278 & 278 \\
\hline \multirow[t]{3}{*}{ Creative } & \begin{tabular}{|l|} 
Pearson \\
Correlation \\
\end{tabular} & $.193 * *$ & $.210 * *$ & $.188 * *$ & $.404 * *$ & $.428 * *$ & 1 & $.508 * *$ \\
\hline & Sig (2-tailed) & .001 & .000 & .002 & .000 & .000 & & .000 \\
\hline & $\mathrm{N}$ & 278 & 278 & 278 & 278 & 278 & 278 & 278 \\
\hline \multirow[t]{3}{*}{ Mean } & \begin{tabular}{|l|} 
Pearson \\
Correlation
\end{tabular} & $.771 * *$ & $.693 * *$ & $.727 * *$ & $.624 * *$ & $.794 * *$ & $.508 * *$ & 1 \\
\hline & Sig (2-tailed) & .000 & .000 & .000 & .000 & .000 & .000 & \\
\hline & $\mathrm{N}$ & 278 & 278 & 278 & 278 & 278 & 278 & 278 \\
\hline
\end{tabular}

** Correlation is significant at the 0.01 level (2-tailed)

According to the output of SPSS 24.0, it found that the sig (2-tailed) score of being faithful and having lofty moral, globally harmonious in diversity, mutually cooperative, autonomous, critical thinking, and creative was $0.000<0.05$. This result indicated a significant correlation between being faithful and having lofty moral attitude and being globally harmonious in diversity attitude. Next, the output of SPSS 24.0 it found that the sig (2-tailed) score of being faithful, noble, pious to The One Almighty God and being globally harmonious in diversity attitude was $0.000<0.05$. It
24.0, it found that the sig (2-tailed) score of between being globally harmonious in diversity and being mutually cooperative attitudes was $0.000<0.05$, indicating a positive correlation between them. Next, the correlation between being globally harmonious in diversity and being autonomous was $0.000<0.05$, indicating a positive correlation as well. The correlation between being globally harmonious in diversity and critical thinking was $0.000<0.05$, indicating a positive correlation as well. The correlation between being globally harmonious in diversity and being creative 
attitude was $0.001<0.05$, indicating a positive correlation as well.

The output of SPSS 24.0 it found that the sig (2tailed) score of being autonomous and critical in thinking resulted in $0.000<0.05$, which indicated a positive correlation between them. The same thing did happen to being autonomous and creative attitude. Their correlation score was $0.000<0.05$, indicating a positive correlation between them.

The output of SPSS 24.0, it found that the sig (2tailed) score of being critical in thinking and creative attitude resulted in $0.000<0.05$, indicating a positive correlation between them. Hence, the more critical in thinking, the more creative the students would be.

Teachers integrated their lesson plan, especially in the aspect of attitude assessment, with the profile of Pancasila, and it was presented in the following figure 3 .

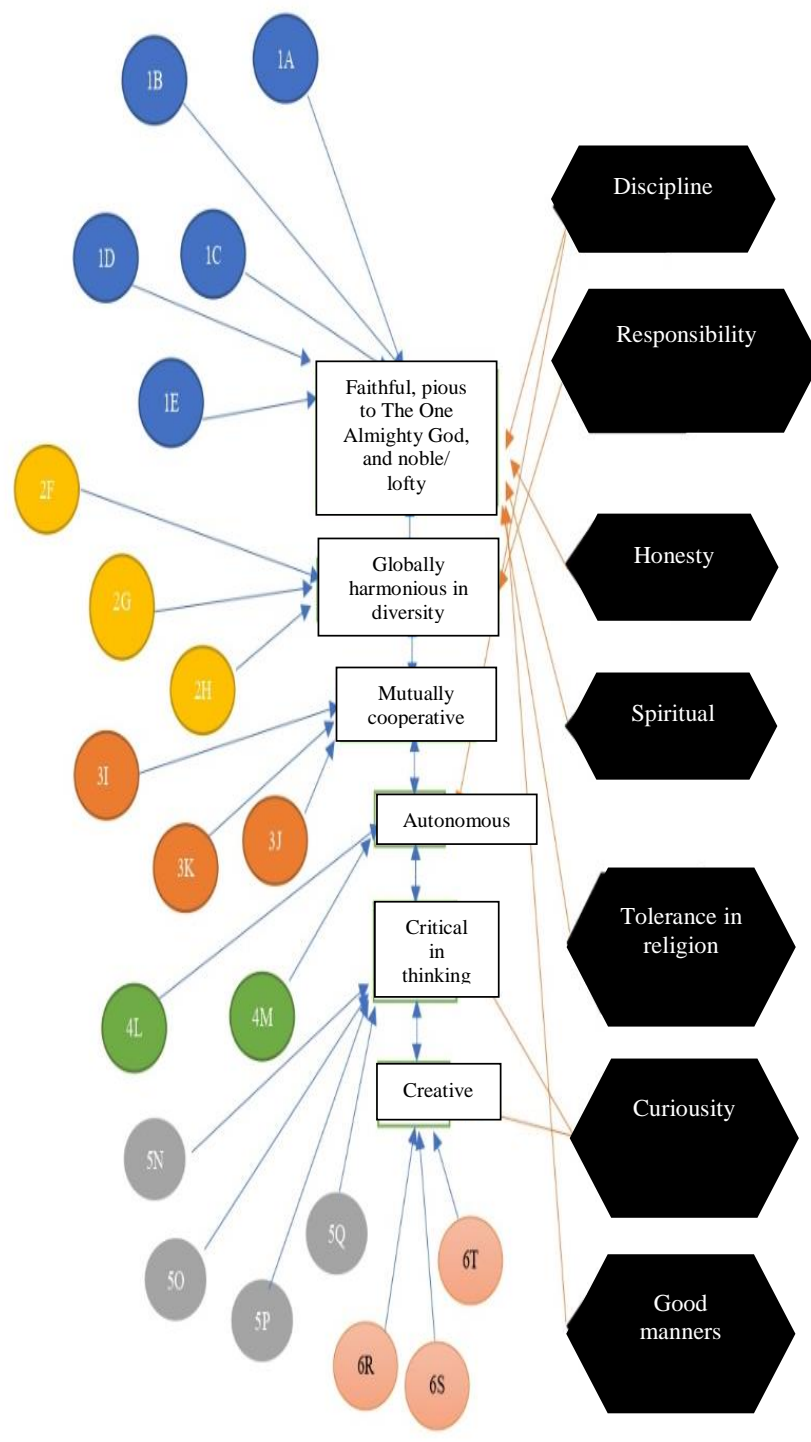

Figure 3. The Integration of Lesson Plan related to Attitudes into the Profile of Pancasila
According to Figure 3, attitudes that teachers tried to show in their lesson plan could not be thoroughly integrated with the profile of Pancasila, yet. They only put some values adopted from character values which referred more to the dimension of being faithful, pious to The One Almighty God, and noble/lofty attitude. For dimension of being globally harmonious in diversity attitude, however, it was merely integrated with responsible character. Unfortunately, dimension of being mutually cooperative was not integrated with character values that teachers tried to show in their lesson plan. On the other hand, dimension of being autonomous attitude was integrated with responsible character. Next, dimension of critical thinking was integrated with responsibility and curiousity. Last, dimension of being creative was integrated with curiousity.

Some attitudes embedded in lesson plan were discipline, responsibility, honesty, spirituality, tolerance in religion, curiousity, and good manners. Teachers put these attitudes as reference to give assessment on students' attitudes during the process of teaching. In relation to the profile of Pancasila, these attitudes intersected to one and anot her as its description. However, teachers mostly knew the implementation between lesson plan and the process of teaching.

During online teaching, teachers gave a standard of attitude assessment adjusted to their students' condition. Yet, it had no clear indicators about how to implement the assessment during the teaching process. Even worse, the attitude assessment they had designed in their lesson plan did not match to the learning objectives. Hence, it indeed affected the result of the assessment which became less optimal and less comprehensive. Teachers merely gave scores for the attitudes they had attached to their lesson plan without considering the sustainability and achievement of the entire attitudes.

In relation to the character values that government had designed, teachers definitely had more extensive illustration about attitude assessment. In fact, they were still less optimal in seeing their students' attitude, especially during the online teaching. The attitude of being autonomous which was not yet integrated with some values of characters as well as the attitude of being creative that teachers should explore to develop students' competence, especially in technology, was one of the actual examples. Teachers could ask their students to utilize any relevant information that might support their online learning. Furthermore, the attitude of being mutually cooperative could be integrated with the value of cooperation character, especially through discussion during online learning. Teachers could utilize various media of online teaching by modifying them in such a way to reveal and develop their students' cooperation in every meeting. 


\section{DISCUSSION}

In designing lesson plan, teachers needed to consider some aspects, especially the criteria of attitude assessment, which instrument should be modified in such a way to measure their students' attitude well. The modification could be in the indicators, teaching objectives, and up to basic competences which students would have and be integrated with the values of attitudes that should develop. Furthermore, teachers could identify each value of attitude adjusted to their assessment. [9][10][11] argued that teachers needed to modify their assessment techniques to either develop or measure the development of their students' attitude during the process of teaching.

Developing students' attitudes should be balanced with teachers' attitude development as well. Teachers were expected to be able to have self-internalization that supported their students' attitude development. This was in line with that teachers were required to have some characters in order to internalize education with good manners. One of those characters was being competent, in which teachers were capable to organize a course and solve various problems to reach their teaching objectives. Next, [12] [13] [14]suggested that education was the heart of national development and was fundamental for people. Therefore, the process of teaching should be centred and useful for students in order to develop their competences optimally. Teachers should apply contextual-based teaching strategies that allowed students to have insights and skills from various learning sources. Hence, teachers should be able to develop an innovative lesson plan using various approaches to develop their students' competences.

Lesson plan definitely affected the teaching and learning process in class, including in online course, as teachers could reflect each of their activities, especially those dealing with assessment system. [15] [16] [17] argued that lesson plan was an important process for teachers in reflecting what they would teach, how to teach, and how to evaluate their teaching. Thus, the process of constructing a lesson plan was a big challenge for every teacher.

\section{CONCLUSION}

In constructing lesson plan, attitude reinforcement that students would receive during online teaching needed to be modified, from direct observation to online form. The assessment of attitudes that should be improved referred to the value of being mutually cooperative attitude by involving students' active participation to work together during group discussion. Besides, teachers needed to thoroughly integrate Pancasila-based attitudes with character values in their lesson plan. Additionally, a clear and measureable instrument was definitely required for assessment.

\section{AUTHORS' CONTRIBUTIONS}

The authors' contributions corresponded to their field and proficiency. Author 1 contributed to conceptualizing and analysing the lesson plan that teachers had designed. Author 2 contributed to numeric analysis and making questionnaire. Author 3 contributed to technology that supported the study.

\section{ACKNOWLEDGMENTS}

This article was one research output of PDUPT (i.e., Penelitian Dasar Unggulan Perguruan Tinggi) scheme supported by grant from DRPM KEMENRISTEKDIKTI in 2021. We also thanked the Head of STKIP PGRI Jombang for motivating and supporting us to participate in grants of PDUPT scheme.

\section{REFERENCES}

[1] H. Iqbal, S. Akhter, and A. Mazid, "Social Sciences \& Humanities Open Rethinking theories of lesson plan for effective teaching and learning," Soc. Sci. Humanit. Open, vol. 4, no. 1, p. 100172, 2021, doi: 10.1016/j.ssaho.2021.100172.

[2] A. Z. Gülten, "Am I Planning well? Teacher Trainees' Voices on Lesson Planning," Procedia Soc. Behav. Sci., vol. 93, no. 2010, pp. 1409-1413, 2013, doi: 10.1016/j.sbspro.2013.10.053.

[3] D. P. N. Brata and A. K. Mahatmaharti, "The implementation of Problem Based Learning (PBL) to develop student's soft-skills," J. Phys. Conf. Ser., vol. 1464, no. 1, 2020, doi: 10.1088/1742$6596 / 1464 / 1 / 012020$.

[4] E. Goyal and S. Tambe, "Effectiveness of MoodleEnabled Blended Learning in Private Indian Business School Teaching Niche," Online J. New Horizons Educ., vol. 5, no. 2, pp. 14-22, 2015.

[5] E. S. Utomo, Juniati, D. Siswono, D. Juniati, and T. Y. E. Siswono, "Exploring Aspects of Mathematical Visualization of Junior High School Student in a Problem-Solving Task," 2018.

[6] N. Nesusin, P. Intrarakhamhaeng, P. Supadol, N. Piengkes, and S. Poonpipathana, "Development of Lesson Plans by the Lesson Study Approach for the 6 th Grade Students in Social Study Subject based on Open Approach Innovation," Procedia Soc. Behav. Sci., vol. 116, pp. 1411-1415, 2014, doi: 10.1016/j.sbspro.2014.01.407.

[7] B. S. Mózo, "Rencana Strategis Kementrian Pendidikan dan Kebudayaan 2020-2024," J. Chem. Inf. Model., vol. 53, no. 9, pp. 1689-1699, 2017, [Online]. Available: file:///C:/Users/User/Downloads/fvm939e.pdf. 
[8] M. Dr. Sandu Siyoto, SKM, M.Kes, M. Ali Sodik, Buku Metode Penelitian Kualitatif dan Kuantitatif, no. March. 2015.

[9] Kemdikbud, "Konsep Dan Pedoman Penguatan Pendidikan Karakter, Pusat Analisis Dan Sikronisasi Kebijakan Sekretariat Jenderal," vol. 17, no. 5, pp. 684-694, 2017, [Online]. Available: https://doi.org/10.1016/j.smr.2019.08.005\%0Ahttp: //dx.doi.org/10.1016/j.smr.2009.02.001\%0Ahttps:// scholarship.shu.edu/student_scholarship.

[10] E. S. Utomo, D. Juniati, and T. Y. E. Siswono, "Mathematical visualization process of junior high school students in solving a contextual problem based on cognitive style," in AIP Conference Proceedings, Aug. 2017, vol. 1868, doi: 10.1063/1.4995138.

[11] M. J. Kintu, C. Zhu, and E. Kagambe, "Blended learning effectiveness: the relationship between student characteristics, design features and outcomes," Int. J. Educ. Technol. High. Educ., vol. 14, no. 1, 2017, doi: 10.1186/s41239-017-0043-4.

[12] D. H. Lim and H. Kim, "Motivation and Learner Characteristics Affecting Online Learning and Learning Application,” J. Educ. Technol. Syst., vol. 31, no. 4, pp. 423-439, 2003, doi: 10.2190/01w0ke8x-mdyh-x27f.

[13] K. Suma, I. W. Mudana, and N. M. Pujani, "Pengembangan Perangkat Pembelajaran
Terintegrasi Pendidikan Karakter Berbasis Tri Hita Karana Di Sekolah Dasar Negeri 1 ...," Proceeding Senadimas ..., pp. 1056-1067, 2020, [Online]. Available:

https://lppm.undiksha.ac.id/senadimas2020/assets/ ProsidingSenadimas2020/file/139.pdf.

[14] A. Sahlan, "Enhancement of Culture in Education: Research on Indonesian High School," Procedia Soc. Behav. Sci., vol. 143, no. 1, pp. 117-121, 2014, doi: 10.1016/j.sbspro.2014.07.371.

[15] M. J. Kintu and C. Zhu, "Student Characteristics and Learning Outcomes in a Blended Learning Environment Intervention in a Ugandan University Mountains of the Moon University and Vrije Universiteit Brussel," Electron. J. e-Learning Vol., vol. 14, no. 3, pp. 181-195, 2016.

[16] J. Coldwell, a Craig, T. Paterson, and J. Mustard, "Online students: Relationships between participation, demographics and academic performance," Electron. J. e-Learning, vol. 6, no. 1, pp. 19-28, 2008, [Online]. Available: http://iucontent.iu.edu.sa/Scholars/Information Technology/Online Students Relationships between Participation, Demographics and Academic Performance.pdf.

[17] D. P. N. Brata, "Developing Pancasila and Civic Education ( Ppkn ) Based on,” vol. 8, no. 1, pp. 768-773, 2020. 